\title{
WPS3581
}

\section{Brain Waste?}

\section{Educated Immigrants in the U.S. Labor Market}

\author{
Aaditya Mattoo, Ileana Cristina Neagu, and Çağlar Özden *
}

\begin{abstract}
World Bank Policy Research Working Paper 3581, April 2005
The Policy Research Working Paper Series disseminates the findings of work in progress to encourage the exchange of ideas about development issues. An objective of the series is to get the findings out quickly, even if the presentations are less than fully polished. The papers carry the names of the authors and should be cited accordingly. The findings, interpretations, and conclusions expressed in this paper are entirely those of the authors. They do not necessarily represent the view of the World Bank, its Executive Directors, or the countries they represent. Policy Research Working Papers are available online at http://econ.worldbank.org.
\end{abstract}

\footnotetext{
* Development Research Group (DECRG), The World Bank, 1818 H Street, NW, Washington, DC 20433; Email: amattoo@worldbank.org, ineagu@worldbank.org, and cozden@worldbank.org, respectively. This paper is part of the World Bank's research programs on Migration and Development as well as Trade in Services, which is supported in part by the United Kingdom Department for International Development. The paper has benefited from the insightful comments by Alan Winters and Maurice Schiff.
} 


\section{Introduction}

Everyone has a story about how they discovered that their taxi driver was an Eastern European scientist. Many taxi drivers, in turn, tell stories about how their Indian passengers are nearly always computer scientists. The purpose of this paper is to investigate the empirical basis for these popular perceptions. We address three related questions. How wide-spread is unskilled employment among educated immigrants? Does the incidence differ with the country of origin of immigrants? Can the differences, if any, be explained by certain observable attributes of the country of origin?

Our results demonstrate, first, the striking differences in the occupational attainment of immigrants with similar educational backgrounds but from different countries. Even after we control for age, experience and education level, we find that highly educated immigrants from certain countries are less likely to obtain skilled jobs. For example, a hypothetical 34 year old Indian college graduate who arrived in 1994, has a $69 \%$ probability of obtaining a skilled job while the probability is only $24 \%$ for a Mexican immigrant of identical age, experience and education. Among the lowest probabilities of obtaining skilled jobs are for several Latin American, Eastern European and Middle Eastern countries. Next, we find that a large part of this country-level variation can be explained by certain country attributes. Some of these attributes affect the quality of human capital accumulated at home, such as expenditure on tertiary education and the use of English as a medium of education. Other attributes lead to a selection effect, i.e. variation in the abilities of migrants because they are drawn from different sections of the skill distribution of their home countries, and include the GDP per capita, the distance to the US, and the openness of US immigration policies to residents of a given country. The existence of military conflict in the home country can have both a quality effect, because it weakens institutions that create human capital, and a selection effect, because it lowers the threshold quality of immigrants.

Our work is related to two strands in the literature on migration. The "assimilation" literature comprises a wide range of rigorous empirical analyses focusing on the performance of migrants in the host country (surveyed in Borjas, 1994). The "brain drain" literature consists of sophisticated theoretical, but rather limited empirical work focusing on the effects of skilled migration, mostly on the home country (surveyed in Commander, Kangasniemi and Winters, 2003). There has, however, been little investigation of the possibility of "brain waste", where the skilled and the educated leave their home country, but then make little use of their skills and education in the host country. 
How immigrants perform in host country labor markets is one of the fundamental questions in the migration literature (Borjas,1994). The existing literature focuses primarily on earnings as a measure of performance. We examine, instead, occupational outcomes, particularly of the highly educated and those with professional qualifications. Earnings do not reveal what immigrants actually do, even though they are likely to be correlated with occupational choices. If the global creation and allocation of human capital are a concern, then it is of interest what kind of jobs the highly educated immigrants obtain. For example, if most university graduates or professionals from a country end up in unskilled jobs when they migrate, then obtaining a better sense of their eventual destiny may help them and their countries improve their allocation of expenditures on education and training.

Early studies in the migration literature note that the similarity of the home country to the United States, and immigration law in the United States may influence the quality distribution of immigrants (Chiswick 1978, 1985). But this empirical research does not really focus on the links between the characteristics of the home country and immigration behavior (Borjas 1985, Chiswick 1985). Jasso and Rosenzweig (1986) make a serious effort to disentangle the root causes of earnings differences across different groups. Their theoretical framework examines how home country conditions influence the decisions to migrate as well as the decisions to remain in the United States after migration. Their results indicate that almost all differences in earnings are eliminated when differences in country characteristics influencing migration and re-migration decisions (such as measures of origin country attractiveness, costs of migration, the quantity and quality of information, and the country specific restrictions of U.S. migration law) are taken into account.

Borjas' (1987) influential paper points out that income-maximizing behavior on the part of potential migrants can create selection biases which are influenced by the characteristics of the home country income distributions. His empirical analysis of the earnings of immigrants from 41 countries using the 1970 and 1980 censuses shows that differences in the U.S. earnings of immigrants with the same measured skills were attributable to variations in political and economic conditions (measured by GNP, level of income inequality, and "competitiveness" of political systems) in the home countries at the time of migration. In particular, persons from Western European countries do quite well in the United States whereas persons from less developed countries perform poorly in terms of earnings. To obtain a more dynamic perspective, Borjas (1991) examines data on immigrants' 
occupations from the 1940,1960, 1970 and 1980 censuses and finds a significant negative trend in immigrant representation in skilled occupations. He argues that the negative trend is due to the shifting source country mix of the U.S. immigration flow in this period. Our results indicate that differences in earnings may reflect not just differences in educational attainments of immigrants from different countries, but also that nominally identical education levels from different countries translate into different human capital levels and job placement.

More recently, Jasso and Rosenzweig (1998) focus on the responses of potential immigrants to changes in the U.S. immigration law regime as well as determinants of demand for immigration in the home country, and the impact of these changes on the skill composition of immigrants. Using a new data set of all new, legal immigrants over the period 1972 through 1995, they find that the average skill of legal immigrants has been rising relative to that of the U.S. population. The main reason is found to be changes in U.S. immigration law, notably the Immigration Act of 1990 that trebled the ceilings for the relatively high-skilled employment visas while at the same time reducing the numbers of low-skilled employment visas issued, and the increase in skill prices in source countries (as measured by GDP per worker). Their results are confirmed in the recent paper by Chiquiar and Hanson (forthcoming) who show that the recent immigrants from Mexico are drawn from the upper-middle section of the wage distribution indicating positive selection effects.

Methodologically, our paper is most closely related to Green (1999), who compares immigrant and native born occupational distributions for Canada. He uses a multinomial logit model of occupational choice and data from the 1981, 1986 and 1991 Canadian censuses. He finds little evidence of immigrants being underrepresented in more skilled occupations relative to native-born workers with similar education and experience characteristics. One reason is the screening by Canadian immigration authorities for more skilled and more educated immigrants under the "points" system. Furthermore, differences in occupational attainment are linked more to linguistic fluency-based differences than differences in source country. Accordingly, no effort is made in the paper to relate outcomes to the differences in home country attributes.

The results of the Green (1999) paper are not in line with other papers on Canada. For example, Baker and Benjamin (1994) find using Canadian data from the 1971, 1981 and 1986 censuses that immigrants earn a lower rate of return on education relative to the native born. Similarly, Green (1995) finds that inability to transfer credentials imposes a severe penalty on the immigrant. These 
findings suggest that within the skilled, it is important to distinguish between occupations with regulatory entry barriers (e.g. the legal and medical professions) and those without.

Reitz (2001) goes further, and estimates that in Canada in 1996 a substantial part of the "immigrant earnings deficit" was due to immigrant skill under-utilization and pay iniquity. However, the evidence presented in the paper suggests only that immigrants obtain a lower return on their aggregate education and experience than that obtained by host country citizens. The attribution of this difference to skill under utilization and pay iniquity rather than lower immigrant skill quality is on the basis of ad hoc assumptions. Given the existing data for Canada and the United States, a disentanglement of the relative importance of these different effects does not seem possible.

Using detailed data from Israel, another country which experienced a large influx of skilled migrants, Friedberg (2000) focuses on the source of the immigrants' human capital. She finds that human capital is imperfectly portable, and the national origin of an individual's education and experience is a crucial determinant of their value in the labor market. The portability of education is found to vary significantly with its level: elementary school education is equally valued, regardless of where it was acquired, but the source of higher education matters. The return to education obtained abroad is found to be higher for immigrants from Europe and the Western Hemisphere than for immigrants from Asia and Africa. But again she makes no effort to link differences in performance to home country attributes. The interesting question of why nominally identical education acquired in different countries produces dramatically different outcomes is thus not addressed.

The other strand of literature relevant to our paper is on the brain drain (see the survey by Commander, Kangasniemi and Winters, 2003). The main focus in this literature has been the negative impact of the migration of skilled individuals on the sending developing countries, due to decline in positive externalities that an educated labor force generates within the economy, lost investments in education and loss of tax revenue (see, for example, Bhagwati and Hamada, 1974 and Bhagwati, 1976). More recent work has pointed to benefits for source countries of return migration, resource repatriation, migrant networks and the flow of information and knowledge (e.g. Puri and Ritzema, 2000, Ratha, 2003). The magnitude of such benefits is likely to depend on how emigrants perform in the host country labor market, and substantial underachievement abroad could diminish potential benefits. 
Another possible positive impact of emigration is through improved incentives to acquire human capital (Mountford, 1997, Vidal, 1998, and Stark, Helmenstein and Prskawetz, 1997, 1998). In this context, Commander et al. (2003) argue that the screening of immigrants in the receiving country is of major importance in determining the welfare implications of brain drain. In effect, if it is known that only the best are selected, then the incentive to acquire additional human capital for the marginal potential migrant is zero. Similarly, if it is known that the rate of return abroad on local educational qualifications is low, then the possibility of emigration offers little additional incentive to acquire human capital.

\section{Data}

Empirical research on issues linked to "brain drain" has been constrained by the scarcity of data. One exceptional source is the US Census which includes detailed information on the social and economic status of foreign-born people in the United States. The data in this paper are from the 1\% sample of the 2000 Census $^{1}$. We restrict our analysis to foreign-educated males who are between 25-65 years old and employed at the time of the census. ${ }^{2}$ Each individual observation in the census has a population weight attached to it which is that representative observation's proportion in the overall US population. We end up with more than 200,000 observations in our dataset which corresponds to around 4.5 million people in the US. Each individual in the census declares an education level and a profession. The education levels are: (1) less than 4 years, (2) 5-9 years, (3) 9-12 years, (4) high-school, (5) some college, (6) bachelors degree, (7) masters degree, (8) professional degree ${ }^{3}$ and (9) doctorate degree.

There are over 500 separate occupations in the census and we group them into six main categories, based on the job description and the average educational attainment ${ }^{4}$ :

(i) Scientist - average education is above 18 years and most people have doctorate degrees; includes medical and life scientists as well as social scientists.

\footnotetext{
${ }^{1}$ Extracts from the Census samples were made through IPUMS (Integrated Public Use Microdata Series), which is a database maintained by Minnesota Population Center at University of Minnesota (http://beta.ipums.org/usa/index.html).

${ }^{2}$ The census asks the respondents their level of education, but not where they obtained it. However, we know the age at which the immigrant entered the United States. So based on this information, we designate a person "US educated" if they arrived in the US before they would have normally finished their declared education level. For example, if a university graduate arrived at the age of 23 or older, then he is considered "foreign educated."

${ }^{3}$ According to census, these are medical, law, optometry, dentistry, pharmacy and veterinary degrees.

${ }^{4}$ Educational attainments were obtained by computing the average years of education in each profession, with all US-born and foreign-born people (males and females) included.
} 
(ii) Professional - average education is above 18 years and most people have professional degrees; includes lawyers and physicians.

(iii) Skilled - average education is above 16 years; includes managers, accountants, engineers, social workers and teachers.

(iv) Professional Support - average education is between 12-16 years and are related to professional categories; includes medical technicians and legal support.

(v) Semi-skilled - the average education is between 12-16 years; includes engineering technicians, police, secretaries and administrative assistants.

(vi) Unskilled - the average education is below 12 years; includes waiters, salespersons, cashiers, construction laborers, automotive mechanics and drivers.

We divide the data into separate cohorts depending on the decade of arrival: 1980s and 1990s. Table 1 provides the distributions of the observations in each cohort across education levels and professional categories. For example, in our sample, we have close to 103,000 foreign-educated men who arrived in the $1990 \mathrm{~s}$. $13 \%$ of them had bachelor's and $18.6 \%$ had high-school degrees. When we look at professional placement, we see that $13.6 \%$ had skilled and $72.7 \%$ had unskilled jobs. In terms of place of origin, 19\% came from Asian and 60\% came from Latin American countries. There are (exactly) 130 countries represented in the sample with Mexico as the home country for around $40 \%$ of the total. When we examine the changes across cohorts, we see that average education levels of immigrants and the ratio of immigrants in higher-skill professions have both gone up in the 1990s. Finally, the ratio of immigrants from most geographic regions stayed stable over time with two exceptions; there is a slight decline from Latin America and Asia and increase from Eastern Europe and developed countries (which include European Union, Canada, Australia and Japan) in the 1990s compared to the 1980s.

The most important variable in our paper is the education level of immigrants. $22.5 \%$ of foreigneducated immigrants arriving in the 1990s have at least a college degree but there is large variation in the educational levels across different home countries (Chart 1). For example, developed countries (defined as above) have the highest average educational levels, but Asia, Eastern Europe, Middle East and Africa are not far behind. Furthermore, the average education levels of immigrants from these countries is higher than the native-born Americans within the comparable sample in the census. Latin American countries, however, present a sharp contrast. For example, only $2 \%$ immigrants from the three largest source countries, Mexico, El Salvador and Guatemala, 
Chart 1: Number of Immigrants in the 1990s - Aggregate and with tertiary education, (thousands)

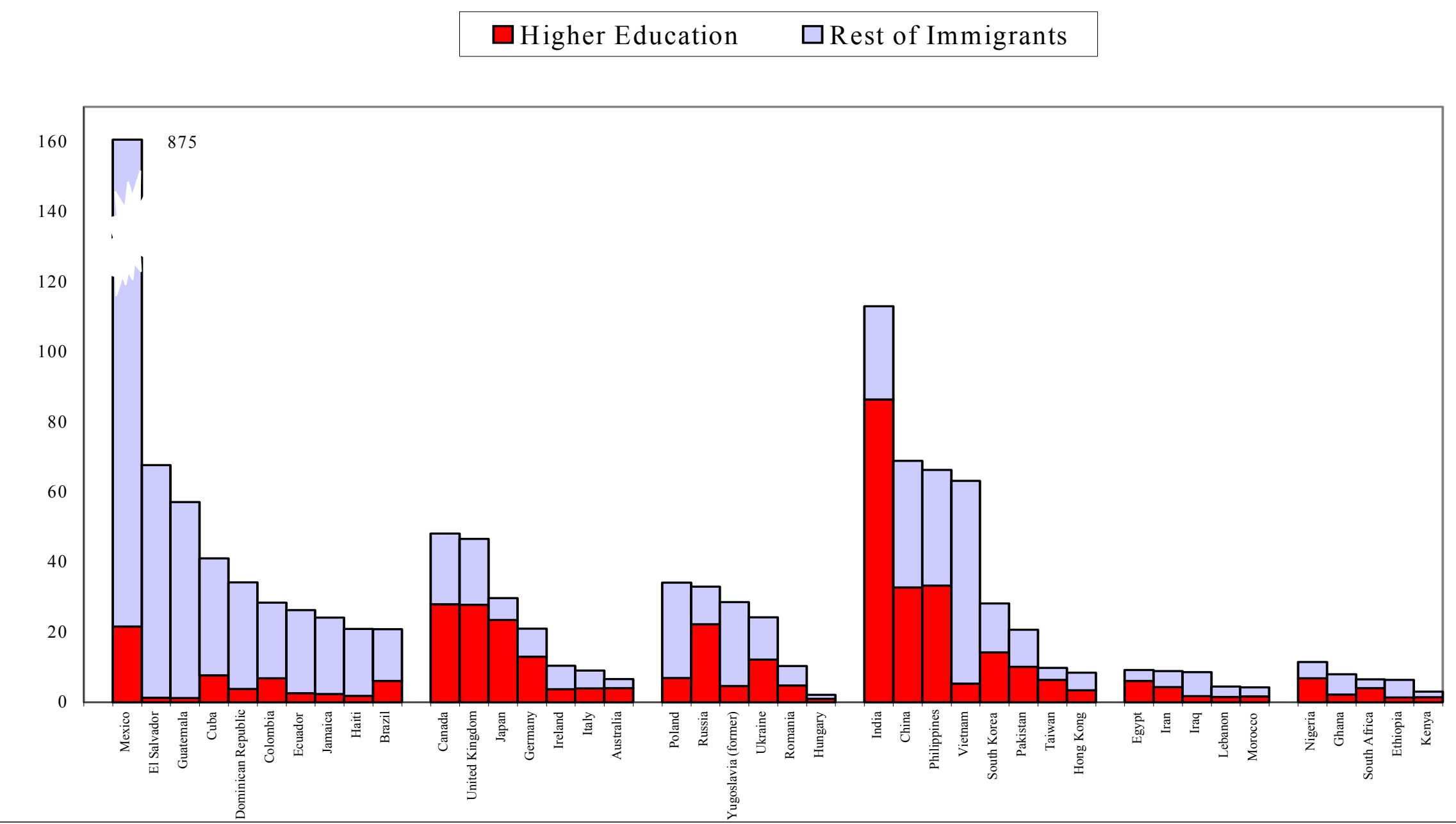


have college or higher degrees. Average level of college attainment for the rest of Latin America in our sample is only $15 \%$.

The differences in educational levels of immigrants from different countries can be due to two separate reasons. First, the average education level in their home countries might vary. Second, the immigrants might be disproportionately drawn from the highly educated (or the uneducated) portions of their native country. Figure 1 depicts the distribution of selected countries along these two dimensions: the proportion with tertiary education among immigrants to the United States against the proportion of tertiary education enrollment in the home country. It is evident that the education level among Latin American immigrants is even lower than the average levels in their home countries. In contrast, immigrants from Africa, Middle East and Asia to the US are on average highly educated even though their home countries have low average education levels. This confirms that immigrants do not constitute a random sample from the population of their home countries, an issue to which we return in the empirical section.

\section{Figure 1: Tertiary education at home and among immigrants to the US, 1990s}

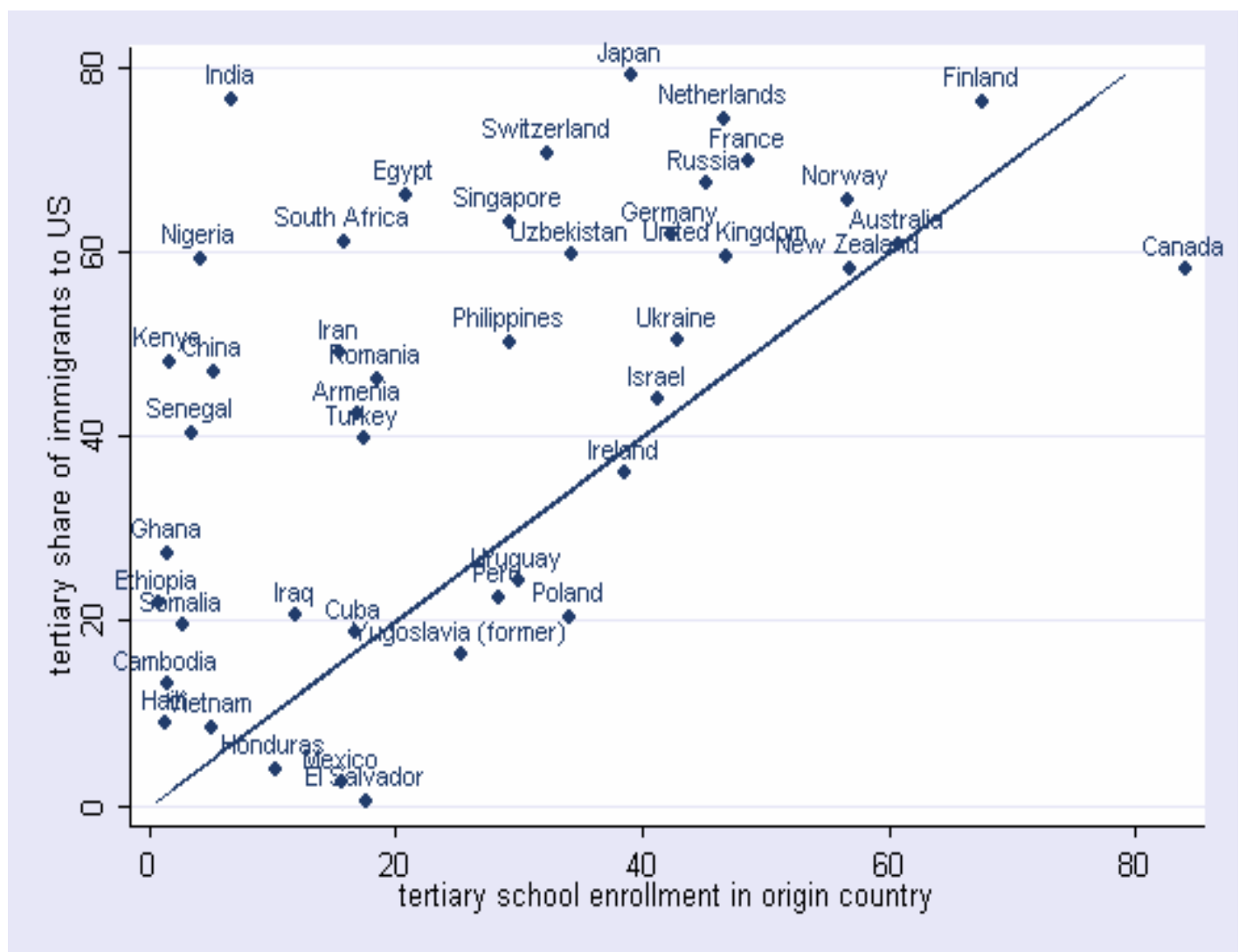




\section{Empirical framework}

Our empirical analysis proceeds in two stages. We first examine how far the labor market placement of immigrants in the United States is attributable to their country of origin, after controlling for the key individual attributes such as education, age and experience. We then explore how much of the variation attributable to the country of origin is explained by differences in observable characteristics of the countries of origin.

\subsection{Does immigrant performance depend on country of origin?}

We use a multinomial logit, which is estimated separately for each cohort. Multinomial logit does not require the set of alternatives to be ordered in any sense. The model for occupational placement is given by

$$
\operatorname{prob}\left(Y_{i}=j\right)=\frac{e^{\beta_{j} x_{i}}}{\sum_{k} e^{\beta_{k j} x_{i}}}
$$

$Y_{i}$, the dependent variable, is the occupational choice for immigrant $i$, and $j$ is one of the six main professional categories identified earlier: science, professional, skilled, professional support, semiskilled and unskilled. The explanatory variables $x_{i}$ are the following:

(i) Education - This is represented through eight different dummy variables which take the value of 1 for the highest degree the individual obtained and zero otherwise.

(ii) Age and Age squared - These approximate for the aggregate experience of the individual. ${ }^{5}$

(iii) Years in the United States and its square - These approximate for the experience of the individual in the US labor market.

(iv) Country dummy variables - These capture all the relevant country characteristics that influence the individual's performance. We use a dummy variable for each one of the 130 countries represented in the sample.

\footnotetext{
${ }^{5}$ It is standard in the literature to use the quadratic form to capture the impact of age and experience, see e.g. Jasso and Rosenzweig (1986).
} 
We perform the multinomial logit estimation separately for each cohort using the population weights of the individuals in the estimation. The coefficients estimated by the logit model are difficult to interpret and we have close to 2,000 coefficients when the country dummies are taken into account which makes it hard to present them ${ }^{6}$. However, the advantage of logit models is that conditional probabilities of specific outcomes can be calculated from the estimated coefficients. Therefore, we calculate probabilities of being in a specific job category for any hypothetical individual with certain characteristics. For example, for the 1990 s cohort, we take a 34 year old who has been in the US for 6 years which are the average age and arrival date in this cohort. Then, we calculate the probability of this individual obtaining a skilled (or any of the other five professions) job for any given combination of education level and home country. This enables us to compare home country effects on labor market outcomes among individuals who have the same degree of education but obtained in different countries. Then, we also explore whether there are significant differences with earlier cohorts. Finally, we take a closer look at immigrants with professional qualifications.

Chart 2 presents estimated probabilities for bachelor and professional degree holders who arrived in the 1990s from a select group of countries. The estimates for all education levels for all 130 countries are presented in Table 2. It is evident that these probabilities vary significantly across countries. A 34 year old Indian who arrived in 1994 and has a bachelors degree, has a 69\% probability of obtaining a skilled job while the probability is only $24 \%$ for a Mexican of identical age, experience and education. Among the lowest probabilities are for several Latin American, Eastern European and Middle Eastern countries. The second column in Table 2 keeps age and years in the US same but increases the education level to a masters degree. The probabilities naturally increase, but even with a masters degree a Mexican still has only a $43 \%$ probability of obtaining a skilled job, while the probability for an Indian is $80 \%$.

\footnotetext{
${ }^{6}$ Given the sample size, almost all of the estimates are statistically significant.
} 
Chart 2: Probability of obtaining a skilled job conditional on education level -1990 s
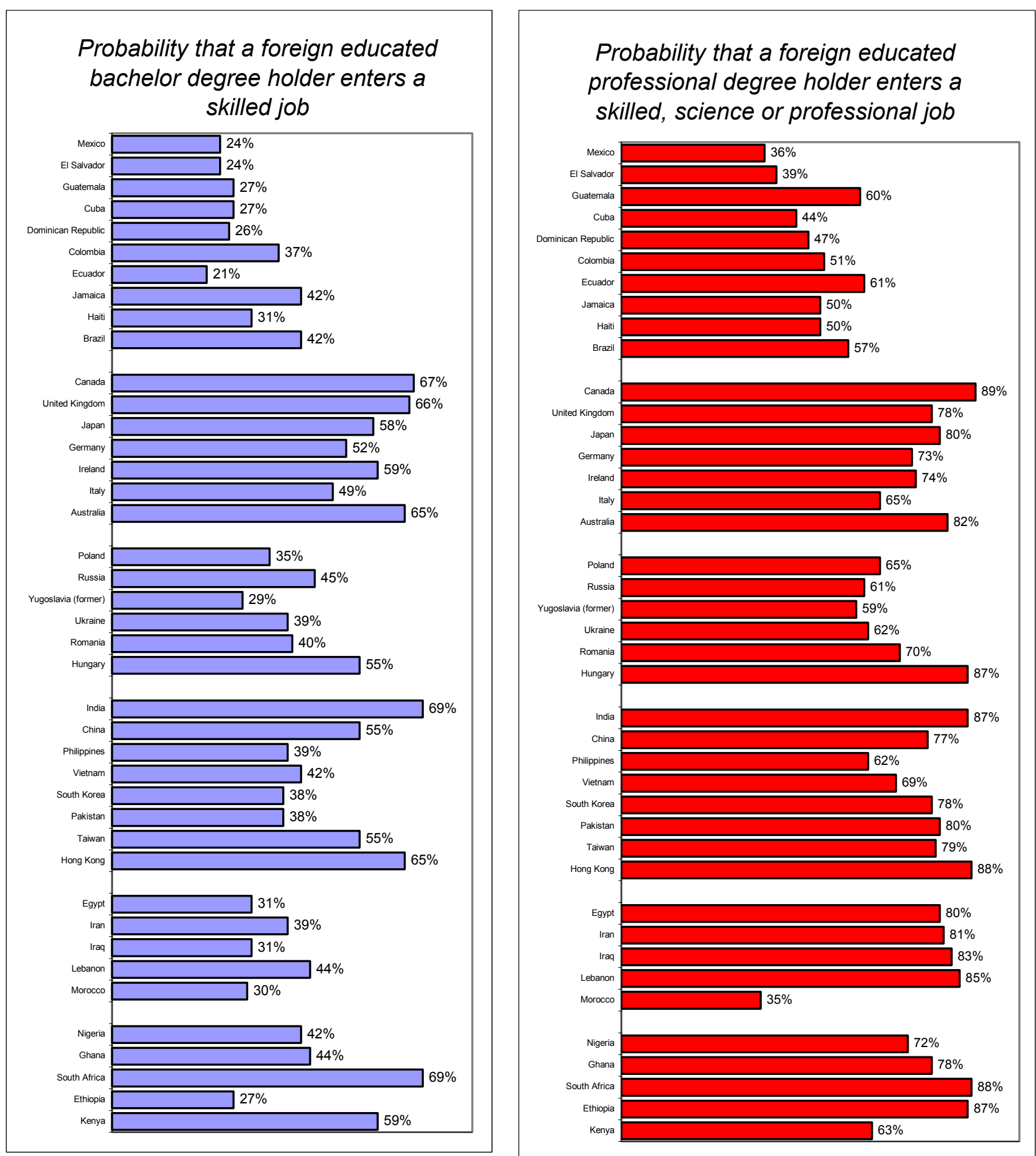

We see that the probability of obtaining a science or professional job is almost zero for individuals with bachelors and masters degree, so we do not report these. However, individuals with a professional degree could well hold other skilled jobs. Although we calculate the probabilities of 
obtaining different types of jobs separately for each education level, we report in Chart 2 and column 3 of Table 2 the sum of the probabilities of obtaining science, professional and other skilled jobs for somebody with a professional degree. (We analyze the performance of professional degree holders in more detail in a later section.) We see that the same relative patterns are maintained and that there are large variations across countries of origin even when individuals have identical age, experience and nominal education. Again, some of the lowest probabilities are for Latin America and Eastern Europe countries, but Middle Eastern professionals perform much better relative to other countries than Middle Eastern graduates. In other words, ostensibly identical educational degrees are not treated equally.

One intriguing question is whether these patterns have changed over time. As emphasized in the literature (see Borjas, 1994), there might be strong cohort differences in the quality of immigrants. In Table 1, we observe that the average education level of immigrants went up considerably over 1990s. While the ratio of immigrants with less than elementary education decreased from $16.4 \%$ to $8.6 \%$, the ratio with at least a college degree increased from $16.9 \%$ to $22.5 \%$.

The shift in the cohort composition is the reason why we estimated the multinomial logit separately for the three cohorts in our data. As in the previous section, we calculate the probabilities of obtaining skilled jobs for individuals with bachelors degrees across cohorts and countries. These are reported in the last two columns of Table 2 The individual in the fourth column is 44 years old and has been in the US for 16 years while the third column is for an individual who is 54 years old and has migrated 26 years ago. Again all of these age and the year of immigration are the mean values for each cohort.

We see in Column 4 that the pattern of cross-country variations is mostly preserved. When we compare columns 1 and 4, however, we see that countries have witnessed significant changes in the performance of their emigrants. Certain countries such as India, China, Kenya, Hungary, Italy and South Africa have witnessed a significant improvement in the $1990 \mathrm{~s}$, whereas the opposite is true for countries like Austria, Egypt, Ethiopia, Indonesia, Nigeria and Uruguay. Apart from changes in the country of origin, these cohort differences might be attributable to changes in the immigration policies of the US: e.g. during the 1980s, a large number of immigrants arrived under flexible family preferences while this policy was tightened in the 1990s. 
The performance of professional degree holders is of particular interest. Do explicit entry barriers in certain professions (such as licensing and other entry requirements in medicine, law etc.) impose additional burdens on certain immigrants and affect their ability to obtain jobs commensurate with their education? In Table 3, we present the probabilities of obtaining different kinds of jobs for individuals with professional degrees for a sample of countries. The top half of the table is for the $1990 \mathrm{~s}$ cohort and the bottom half is for the 1980s. The representative individual from the 1990s cohort is again 34 years old and has been in the US for 6 years. We see, for example, if the immigrant came from Canada, there is a $62 \%$ probability that he will obtain a professional job, $4 \%$ probability of a science job and $23 \%$ probability of another skilled job. In fact, immigrants from ex-British colonies, such as Canada, India, Egypt and Nigeria, seem to be especially successful in obtaining professional jobs. We investigate this further in the next section, but note that this may be due to the compatibility of educational and professional systems (such as law) as well as the advantage of sharing a common language. The next observation is that immigrants from other developed countries, such as United Kingdom obtain a relatively large number of skilled jobs, including managerial positions. Interestingly, the Chinese and Japanese immigrants are relatively highly represented in science related jobs. Finally, immigrants from Latin American countries, such as Mexico and Brazil, and Eastern European countries, such as Russia, have high probabilities on ending up with unskilled jobs.

The results from the 1980 s cohorts are slightly different. With some exception, immigrants who arrived in the 1980s, particularly from Russia, Brazil, Vietnam and Mexico, have a higher probability of obtaining professional jobs compared to the 1990s cohort. One explanation could be that there are differences in quality across cohorts. The second is that it takes time to overcome the various hurdles to enter a profession. Since we do not have data on exactly when an individual obtains a professional job, it is hard to identify the real cause.

\section{What explains immigrant performance differences across countries of origin?}

The previous section established that there is large variation in terms of labor market placements among similarly educated immigrants depending on their home countries. If the labor market in the United States is efficient and there is no discrimination, then the probabilities we calculated in the previous section reflect the "average quality" of the immigrants from a particular country in a particular cohort. In this section, we aim to identify the determinants of the "quality" differences by country of origin. 
The previous literature (beginning with Borjas (1987) and Jasso and Rosenzweig (1986)) has sought to explain differences in the earnings of individual immigrants on the basis of differences in their levels of education and other explanatory variables which typically include source country attributes. Instead, we seek to explain differences in the occupational placement of individuals who have nominally identical levels of education. In terms of the conventional analysis, our exercise can be seen as an examination of the interaction between levels of education and other relevant variables, but as far as we know such an analysis has not been previously undertaken.

We divide our explanatory variables into two categories. Quality variables explain why nominally identical educational qualifications obtained in different source countries are valued differently in the US labor market. Selection variables explain why even if we control for differences in the quality of education, the abilities of migrants from different source countries differ because they are drawn from different segments of the source country ability distribution.

As our dependent variable, we use the different probabilities estimated using the multinomial logit in the previous section, defined as $p_{k t}$, where $k$ is for country and $t$ is for cohort:

$p_{k t}=\alpha+\beta_{1} D I S T_{k}+\beta_{2} C O N F L I C T_{k t}+\beta_{3} E N G L I S H_{k}+\beta_{4} E D U C \_\exp _{k t}+\beta_{5} G D P_{k t}$ $+\beta_{6} F P_{k t}+\varepsilon_{k t}$

Note that the above equation is estimated separately for each cohort to isolate cohort effects. The explanatory variables are: natural log of the distance to US (DIST); the presence of military conflict (CONFLICT); English language dummy (ENGLISH); natural log of tertiary education expenditure per student (EDUC_exp); natural log of the GDP per capita (GDP); ratio of immigrants obtaining residency rights by means such as family preferences, visa lotteries and political asylum, to population of origin country (FP). Detailed definitions and data sources for these variables are available in the Data Appendix.

In the class of quality variables, we include the natural $\log$ of tertiary education expenditure (EDUC_exp) per student during the relevant period adjusted for purchasing power parity, and a dummy variable (ENGLISH) that takes the value of 1 if English is the spoken language in the home country. Both these variables can be expected to have a positive influence on the individual's human capital and lead to more favorable occupational placement in the US labor market. 
In the class of selection variables, we include, first of all, a set of source country variables: natural $\log$ of the home country GDP per capita adjusted for purchasing power parity, distance from the United States (DIST) and a dummy variable (CONFLICT) that reflects the presence of military conflict in the home country during the decade the migrant arrived in the US.

Instead of just home country GDP, it would have been preferable to have data on the average earnings of graduates or professionals, and the distribution of such earnings, but such data are available only for a small number of countries. For higher GDP countries, the opportunity cost of migrating is high, and so only individuals with high income potential would emigrate to and remain in the United States. Furthermore, as Borjas (1987) has argued, since the distribution of income in many of the other industrial countries is more equal than that in the United States, we would again expect those at the upper tail of home country distributions to migrate to the United States. For countries with per capita GDP substantially lower than that of the United States, the relative distribution of income is irrelevant and it can be assumed that both low and high ability individuals would wish to migrate. But it is conceivable that in some of the poorest countries only the more capable have the means to migrate. So source country GDP per capita is likely to matter, but there is only a weak presumption that it will have a positive association with the probability of obtaining a skilled job.

Distance has conventionally been regarded as an important determinant of the cost of migration, but it too has a somewhat ambiguous influence. On the one hand, it can be seen as reflecting the cost of migration, which would suggest a positive selection effect: only those who expect to do well would be willing to incur the costs of travel. A second related reason is that people from distant countries (such as in Asia, Africa or the Middle East) may have closer migration options (such as Europe and the Persian Gulf). If the US rewards human capital more than these other destination countries, then immigrants will again self select and US will attract the higher quality migrants from distant countries. On the other hand, distance also reflects the cost of return (Borjas and Bratsberg, 1996 and Jasso \& Rosenzweig, 1986). If migrants are not fully informed about their prospects, and these are revealed to them only on arrival in the United States, then it would be less costly for a disappointed Mexican to return home than a disappointed Russian. Since our data pertains to those who came to the US and decided not to return home, both effects are present. 
The presence of conflict in the home country can be expected to lower the threshold of those who would want to migrate because it reduces the opportunity cost of staying. In low GDP countries, where the desire to migrate is not in question and the constraint is the means to migrate, the existence of conflict may still act as a powerful push factor. Furthermore, political instability might also have a quality effect, causing a decline in human capital accumulation of the citizens and make them less qualified for high-skilled jobs in the US. So we would expect a negative influence of conflict on achievement.

The final, and perhaps most critical, selection variable is not an attribute of the source country but the immigration policies of the host country. There are three main ways to legally enter the United States. These are (i) through family preferences, (ii) lottery for underrepresented nationalities and refugees and (iii) skills based programs such as the $\mathrm{H}-1$ visas where a prior offer of employment commensurate with skills is a requirement for entry. The first two routes do not discriminate between immigrants based on their education or skill levels but the third one has strict skill requirements. If there are already many immigrants from a country, then family preferences makes it easier for potential immigrants from that country to enter the US. On the other hand, if the family preferences, lottery and asylum policies were restricted, we should expect to see an improvement in the average human capital of immigrants because $\mathrm{H}-1$ becomes the primary route.

\subsection{Empirical results}

Table 4 presents the sample statistics for these variables for each cohort. The tertiary education expenditure seems to decline over time - from $\$ 5,625$ in the 1970 s to $\$ 4,625$ in the $1980 \mathrm{~s}$, and further to $\$ 4,039$ in the $1990 \mathrm{~s}$. However, this is likely to be because more observations are available for the more recent decades, and the additional data generally came from poorer developing countries.

In Table 5, we present the results from an OLS regression with robust standard errors and weighted by the number of immigrants from each country in the 1990s cohort within that education level. To begin with we do not include the US immigration policy variable, FP. In the first column, the dependent variable is the country-specific probability that a 34 year old with college degree who has been in the US for 6 years obtains a skilled job. Distance, English and Tertiary education expenditure have positive and significant coefficients while Military conflict is negative and significant. GDP per capita is not significant. The same pattern exists with the coefficients of 
Military conflict, English and Tertiary education expenditure variables for masters and professional degrees as can be seen in columns 2 and 3. The only difference is with the masters degree in the second column where Distance is not significant while GDP is.

The results imply that immigrants from countries where English is a common language and expenditure on tertiary education is high perform better in the US labor market. This is not surprising as both increase the relevant human capital of the immigrants for the US labor market. For example, coming from an English speaking country increases the likelihood of obtaining a skilled job in the US by $11 \%$ for a hypothetical college graduate. Similarly, $10 \%$ increase in tertiary education increases the same probability by $7.5 \%{ }^{7}$.

Distance has a positive effect on average immigrant quality, suggesting the costs of migrating effect is stronger than the costs of return effect. And the negative sign on the coefficient of the military conflict variable implies that the average quality of immigrants seem to increase with political stability.

The parallel regressions for the 1980s cohort are presented in Table 6. We have fewer countries in this regression since the tertiary education data is not available for many developing countries for the earlier decades. When we compare the results with the 1990s, the main change is that the Military conflict and English dummies are only significant for the Masters and Professional degrees, respectively. English might decline in importance as the immigrants stay longer in the US and master the language, thus is no longer significant in the first two columns. But it might also be a proxy for the legal and educational compatibility of the country with the US and, thus, stays significant in the last column for the professional education categories. Tertiary education expenditure continues to be significant, indicating the importance of educational quality of the home country on the success of the citizens in the US labor market, even decades after migration.

Consider now how explicit consideration of US migration policies impacts on the quality of immigrants. We introduce the variable $F P_{i t}$ into the regressions above for the 1990 s cohort and present the results in Table 7 . The coefficient is negative and significant, implying that the average

\footnotetext{
${ }^{7}$ An alternative estimation strategy could be to include these country specific variables in the multinomial logit instead of the country dummies. Then we can calculate the marginal impact of a change in one of these explanatory variables on the probability of an individual to obtain a skilled job. We performed this estimation and the results are almost identical, as expected. For example, the impact of an English dummy is $12 \%$ increase in the probability of obtaining a skilled job for a 34 year old who entered the US in 1994. Similarly, the impact of a conflict is a decline of $13 \%$ in the same probability for an identical migrant.
} 
quality of immigrants from a given country declines as these immigration programs are widened. All other variables' coefficients maintain their size and significance, except the distance variable, possibly because distance is also a determinant of the selection of the immigrants and is correlated with our new variable. Clearly, if the US were to restrict the family preferences, lottery and other non-skill based programs, there would be a positive effect on the overall quality of the migrants.

\section{Conclusion}

This paper investigates the occupational performance of educated immigrants using US census data. We find striking differences among immigrants from different countries of origin which could not be explained by differences relating to individuals' age, experience and level of education. With some exceptions, educated immigrants from Latin America and Eastern Europe perform poorly, especially when compared to immigrants from developing countries in Asia and developed countries. Middle Eastern and African college graduates do not do well but the professionals from these regions are relatively successful.

We found that a large part of the variation across countries can be explained by attributes of the country of origin that influence the quality of relevant human capital, such as expenditure on tertiary education and the use of English as a medium of instruction. Performance is also adversely affected by conflict at home, which could have both a quality impact by weakening the institutions that create human capital, and a selection effect, by lowering the threshold quality of immigrants. US immigration policy also plays a critical role in explaining cross-country variation because a large proportion of immigrants from some countries (such as Mexico) are admitted through family preferences, visa lotteries and political asylum, whereas more immigrants from other countries (such as India) have to rely on employment preferences.

Our results have implications for policy. Today, public and private resources are being devoted in many developing countries to providing university and professional education to those who may end up in jobs (domestically and abroad) that make little use of their education. Obtaining a better sense of their eventual destiny should help individuals and their countries improve their allocation of resources for education. For example, if there is a high likelihood of migrating to the US, then there may be a higher return to learning English than obtaining an additional degree which is not valued in the US labor market. Greater cooperation between home and host countries, including 
information sharing about potential needs in the host labor market and predictable visa regimes, would help source countries better plan their investments in human capital.

Non-recognition of foreign qualifications and licenses is clearly a big barrier to entry into many skilled jobs. Denial of recognition may be legitimate when home country qualifications are inadequate, but in some cases the burdensome re-qualification requirements imposed on foreigners reflect the protectionist capture of regulatory processes by domestic vested interests. Our results may suggest that individuals educated in some countries are better equipped to overcome these barriers, mainly because of greater compatibility of educational or training standards with the US. However, the differences are exaggerated: the fact that residents of some countries mostly obtain visas (H1-B and employment preferences) conditional on an offer of employment implies that the visa process and the recognition process are de facto combined. In the case of other countries, where the two processes are separate, there is greater scope for educated individuals to enter and then begin the struggle to obtain recognition, and hence greater scope for waste. In either case, more needs to be done, possibly in the context of the services negotiations currently taking place at the World Trade Organization, to ensure that qualification and licensing requirements imposed on foreigners are not more burdensome than necessary to achieve legitimate regulatory objectives.

Finally, despite the usefulness of these findings, we remain far from answering the question in the title of our paper, whether there is in fact brain waste. A proportion of the variation in the performance of immigrants remains unexplained. Is this due to unobserved yet human capital relevant attributes of the country of origin? Or is it because the market is unfairly and inefficiently penalizing origin? Given the state of the data, these must remain questions for future research. 


\section{References}

Baker, M., Benjamin, D., 1994. "The Performance of Immigrants in the Canadian Labor Market," Journal of Labor Economics 12, 369-405.

Bhagwati, J., Hamada, K., 1974. "The Brain Drain, International Integration of Markets for Professionals and Unemployment: A Theoretical Analysis," Journal of Development Economics 1, $19-42$.

Bhagwati, J. (ed.), 1976. The Brain Drain and Taxation, Theory and Empirical Analysis. North Holland.

Borjas, G., 1985. "Assimilation, Changes in Cohort Quality, and the Earnings of Immigrants," Journal of Labor Economics 3, 463-489.

Borjas, G., 1987. "Self-Selection and Earnings of Immigrants," American Economic Review 77, 531-553.

Borjas, G., 1991. "National Origin and the Skills of Immigrants in the Postwar Period," NBER Working Paper 3575.

Borjas, G., 1994. “The Economics of Immigration," Journal of Economic Literature 32, 16671717.

Borjas, G., Bratsberg, B., 1996. "Who Leaves? The Outmigration of the Foreign-Born," Review of Economics and Statistics 78, 165-176.

Chiquiar, D. and G. Hanson, forthcoming, "International Migration, Self-selection, and the Distribution of Wages: Evidence from Mexico and the United States, Journal of Political Economy

Commander, S., Kangasniemi M., Winters L.A., 2003. “The Brain Drain: Curse or Boom?” IZA Discussion Paper 809.

Chiswick, B. R., 1978. "The Effect of Americanization of the Earnings of Foreign-Born Men," Journal of Political Economy 86, 897-921.

Chiswick, B. R., 1985. "Is the New Immigration More Unskilled Than the Old?" Hoover Institution, Working Paper No. E-85-6.

Friedberg, M. R., 2000. "You Can't Take It with You? Immigrant Assimilation and the Portability of Human Capital," Journal of Labor Economics 18, 221-251.

Green, D.A., 1995. "The Early Adjustment of Immigrants: Credentials Recognition and Earnings Growth," Discussion Paper 95-12, Department of Economics, University of British Columbia. Vancouver.

Green, D.A., 1999. "Immigrant Occupational Attainment: Assimilation and Mobility over Time," Journal of Labor Economics 17, 49-79. 
Jasso, G., Rosenzweig, M. 1986. "What's in a Name? Country-of-Origin Influences on the Earnings of Immigrants in the United States," in: Research in Human Capital and Development vol. 4, Oded Stark (ed), Greenwich.

Jasso, G., Rosenzweig, M., Smith, J. P., 1998. "The Changing Skill of New Immigrants to the United States: Recent Trends and Their Determinants," NBER Working Paper 6764.

Mountford, A., 1997. "Can a Brain Drain Be Good for Growth in the Source Economy?," Journal of Development Economics 53, 287-303.

Puri, S., Ritzema, T., 2000. "Migrant Worker Remittances, Micro-finance and the Informal Economy: Prospects and Issues," International Labour Office, Social Finance Unit, Working Paper 21.

Ratha, D., 2003. "Workers' Remittances: An Important and Stable Source of External Development Finance". Chapter 7. Global Development Finance 2003, World Bank.

Reitz, J. H., forthcoming. "Immigrant Skill Utilization in the Canadian Labour Market: Implications of Human Capital Research,”. Journal of International Migration and Integration.

Stark, O., Helmenstein, C., Prskawetz A., 1997. “A Brain Gain with a Brain Drain,” Economics Letters 55, 227-234.

Stark, O., Helmenstein, C., Prskawetz A., 1998. "Human Capital Depletion, Human Capital Formation, and Migration: a Blessing or a Curse?," Economics Letters 60, 363-367.

Vidal, J-P., 1998. "The Effect of Emigration on Human Capital Formation," Journal of Population Economics 11, 589-600. 


\section{DATA APPENDIX}

\begin{tabular}{|c|c|c|}
\hline VARIABLE & DEFINITION & SOURCE \\
\hline DIST & Natural log of distance to the US in miles & $\begin{array}{l}\text { Andrew Rose datasets available at } \\
\text { http://faculty.haas.berkeley.edu/arose/ }\end{array}$ \\
\hline CONFLICT & $\begin{array}{l}\text { The presence of military conflict in the } \\
\text { home country during the decade migrant } \\
\text { arrived in the US. CONFLICT is a dummy } \\
\text { variable with value } 1 \text { if there has been a } \\
\text { conflict. }\end{array}$ & $\begin{array}{l}\text { Variable constructed using } \\
\text { www.prio.no, "Armed Conflict } \\
\text { Version 2.1" by Gleditsch, } \\
\text { Wallensteen, Eriksson, Sollenberg } \\
\text { and Strand (2004) }\end{array}$ \\
\hline ENGLISH & $\begin{array}{l}\text { English as a main language - dummy } \\
\text { variable with value } 1 \text { if English is the main } \\
\text { spoken language. }\end{array}$ & CIA - The World Factbook, 2002 \\
\hline EDUC_exp & $\begin{array}{l}\text { Natural log of tertiary education } \\
\text { expenditure (average annual expenditure } \\
\text { per student per decade, adjusted for PPP) }\end{array}$ & WDI-World Development Indicators \\
\hline GDP & $\begin{array}{l}\text { Natural log of per capita GDP adjusted for } \\
\text { PPP }\end{array}$ & WDI-World Development Indicators \\
\hline FP & $\begin{array}{l}\text { Ratio of those immigrants who entered the } \\
\text { US under family preferences, lottery and } \\
\text { asylum, in the } 1990 \text { s to the total population } \\
\text { of the country in } 1990 \text {. }\end{array}$ & $\begin{array}{l}\text { USCIS- Yearbook of Immigration } \\
\text { Statistics }\end{array}$ \\
\hline
\end{tabular}




\section{TABLE 1 - Description of data}

\begin{tabular}{||l|c|c|c||}
\hline & $1990 \mathrm{~s}$ & $1980 \mathrm{~s}$ & $1970 \mathrm{~s}$ \\
\# in the sample & 102,785 & 70,061 & 31,985 \\
Corresponding population & $2,270,463$ & $1,511,287$ & 667,641 \\
\hline Distribution by Education categories & & & \\
Less than 4 & $8.6 \%$ & $11.4 \%$ & $16.4 \%$ \\
5 to 9 & $26.2 \%$ & $26.2 \%$ & $26.5 \%$ \\
10 to 12 & $12.7 \%$ & $12.6 \%$ & $10.9 \%$ \\
High-school & $18.6 \%$ & $18.0 \%$ & $15.5 \%$ \\
Some college & $11.4 \%$ & $14.1 \%$ & $13.7 \%$ \\
Bachelor's degree & $13.0 \%$ & $10.7 \%$ & $10.9 \%$ \\
Master's degree & $6.1 \%$ & $4.6 \%$ & $4.1 \%$ \\
Professional degree & $1.8 \%$ & $1.2 \%$ & $1.3 \%$ \\
Doctorate degree & $1.6 \%$ & $1.1 \%$ & $0.6 \%$ \\
\hline \hline Distribution by Profession categories & & & \\
Skilled & $13.6 \%$ & $10.3 \%$ & $10.9 \%$ \\
Science & $0.9 \%$ & $0.4 \%$ & $0.4 \%$ \\
Professional & $0.7 \%$ & $0.6 \%$ & $0.9 \%$ \\
Professional support & $1.2 \%$ & $1.3 \%$ & $1.2 \%$ \\
Technician & $11.0 \%$ & $14.1 \%$ & $14.7 \%$ \\
Unskilled & $72.7 \%$ & $73.4 \%$ & $71.9 \%$ \\
\hline Distribution by Continents & & & \\
Latin America & $60 \%$ & $62 \%$ & $59 \%$ \\
Asia & $19 \%$ & $22 \%$ & $20 \%$ \\
Developed Countries & $9 \%$ & $7 \%$ & $11 \%$ \\
Eastern Europe & $7 \%$ & $4 \%$ & $3 \%$ \\
Middle East & $3 \%$ & $3 \%$ & $4 \%$ \\
Africa & $3 \%$ & $2 \%$ & $2 \%$ \\
\hline \hline
\end{tabular}


TABLE 2 -Probability of Obtaining Skilled Jobs - Different Cohorts and Education Levels for 130 countries

\begin{tabular}{|c|c|c|c|c|c|}
\hline $\begin{array}{l}\text { Cohort } \\
\text { Education Level }\end{array}$ & $\begin{array}{c}\text { 1990s } \\
\text { Bachelor }\end{array}$ & $\begin{array}{c}\text { 1990s } \\
\text { Masters }\end{array}$ & $\begin{array}{c}\text { 1990s } \\
\text { Professional }\end{array}$ & $\begin{array}{c}\text { 1980s } \\
\text { Bachelor }\end{array}$ & $\begin{array}{c}\text { 1970s } \\
\text { Bachelor }\end{array}$ \\
\hline Afghanistan & $22 \%$ & $38 \%$ & $18 \%$ & $26 \%$ & $31 \%$ \\
\hline Africa, ns/nec & $36 \%$ & $52 \%$ & $54 \%$ & $39 \%$ & $55 \%$ \\
\hline Albania & $14 \%$ & $29 \%$ & $58 \%$ & $14 \%$ & $0 \%$ \\
\hline Algeria & $31 \%$ & $49 \%$ & $66 \%$ & $10 \%$ & $78 \%$ \\
\hline Antigua-Barbuda & $66 \%$ & $78 \%$ & $68 \%$ & $26 \%$ & $26 \%$ \\
\hline Argentina & $51 \%$ & $65 \%$ & $70 \%$ & $42 \%$ & $43 \%$ \\
\hline Armenia & $21 \%$ & $37 \%$ & $39 \%$ & $28 \%$ & $18 \%$ \\
\hline Australia & $65 \%$ & $74 \%$ & $82 \%$ & $64 \%$ & $58 \%$ \\
\hline Austria & $43 \%$ & $58 \%$ & $42 \%$ & $62 \%$ & $48 \%$ \\
\hline Azerbaijan & $41 \%$ & $60 \%$ & $39 \%$ & $46 \%$ & $0 \%$ \\
\hline Azores & $0 \%$ & $0 \%$ & $0 \%$ & $50 \%$ & $46 \%$ \\
\hline Bahamas & $52 \%$ & $67 \%$ & $95 \%$ & $34 \%$ & $0 \%$ \\
\hline Bangladesh & $21 \%$ & $37 \%$ & $69 \%$ & $23 \%$ & $28 \%$ \\
\hline Barbados & $56 \%$ & $70 \%$ & $91 \%$ & $41 \%$ & $36 \%$ \\
\hline Belgium & $63 \%$ & $74 \%$ & $67 \%$ & $48 \%$ & $62 \%$ \\
\hline Belize/British Honduras & $43 \%$ & $59 \%$ & $90 \%$ & $45 \%$ & $37 \%$ \\
\hline Bermuda & $63 \%$ & $78 \%$ & $65 \%$ & $49 \%$ & $20 \%$ \\
\hline Bolivia & $22 \%$ & $39 \%$ & $61 \%$ & $30 \%$ & $48 \%$ \\
\hline Brazil & $42 \%$ & $59 \%$ & $57 \%$ & $36 \%$ & $49 \%$ \\
\hline Bulgaria & $37 \%$ & $56 \%$ & $65 \%$ & $27 \%$ & $0 \%$ \\
\hline Myanmar & $27 \%$ & $43 \%$ & $83 \%$ & $41 \%$ & $40 \%$ \\
\hline Byelorussia & $34 \%$ & $54 \%$ & $34 \%$ & $49 \%$ & $59 \%$ \\
\hline Cambodia & $58 \%$ & $75 \%$ & $56 \%$ & $29 \%$ & $49 \%$ \\
\hline Cameroon & $29 \%$ & $44 \%$ & $27 \%$ & $7 \%$ & $32 \%$ \\
\hline Canada & $67 \%$ & $76 \%$ & $89 \%$ & $54 \%$ & $59 \%$ \\
\hline Cape Verde & $0 \%$ & $0 \%$ & $0 \%$ & $18 \%$ & $53 \%$ \\
\hline Chile & $37 \%$ & $51 \%$ & $69 \%$ & $45 \%$ & $43 \%$ \\
\hline China & $55 \%$ & $68 \%$ & $77 \%$ & $42 \%$ & $38 \%$ \\
\hline Colombia & $37 \%$ & $55 \%$ & $51 \%$ & $32 \%$ & $36 \%$ \\
\hline Costa Rica & $36 \%$ & $56 \%$ & $40 \%$ & $23 \%$ & $50 \%$ \\
\hline Cuba & $27 \%$ & $44 \%$ & $44 \%$ & $33 \%$ & $45 \%$ \\
\hline Cyprus & $21 \%$ & $31 \%$ & $95 \%$ & $62 \%$ & $36 \%$ \\
\hline Czech Republic and Slovakia & $34 \%$ & $52 \%$ & $42 \%$ & $32 \%$ & $41 \%$ \\
\hline
\end{tabular}




\begin{tabular}{||l} 
Denmark \\
Dominica \\
Dominican Republic \\
Ecuador \\
Egypt \\
El Salvador \\
Eritrea \\
Ethiopia \\
Europe, ns. \\
Fiji \\
Finland \\
France \\
Georgia \\
Germany \\
Ghana \\
Greece \\
Grenada \\
Guatemala \\
Guyana/British Guiana \\
Kuwait \\
Laos \\
Latvia \\
Haiti \\
Jordan \\
Honduras \\
Hong Kong \\
Hungary \\
India \\
Israly \\
Indochina, ns \\
Indonesia \\
Iran \\
Iraq \\
Ireland \\
Israel \\
Inang
\end{tabular}

\begin{tabular}{|c|c|c|c|c|}
\hline $58 \%$ & $69 \%$ & $79 \%$ & $35 \%$ & $47 \%$ \\
\hline $0 \%$ & $0 \%$ & $85 \%$ & $8 \%$ & $44 \%$ \\
\hline $26 \%$ & $43 \%$ & $47 \%$ & $30 \%$ & $25 \%$ \\
\hline $21 \%$ & $38 \%$ & $61 \%$ & $27 \%$ & $27 \%$ \\
\hline $31 \%$ & $49 \%$ & $80 \%$ & $36 \%$ & $49 \%$ \\
\hline $24 \%$ & $43 \%$ & $39 \%$ & $26 \%$ & $35 \%$ \\
\hline $32 \%$ & $48 \%$ & $92 \%$ & $49 \%$ & $75 \%$ \\
\hline $27 \%$ & $42 \%$ & $87 \%$ & $40 \%$ & $41 \%$ \\
\hline $40 \%$ & $56 \%$ & $49 \%$ & $20 \%$ & $36 \%$ \\
\hline $35 \%$ & $46 \%$ & $94 \%$ & $50 \%$ & $44 \%$ \\
\hline $49 \%$ & $62 \%$ & $52 \%$ & $43 \%$ & $51 \%$ \\
\hline $54 \%$ & $67 \%$ & $77 \%$ & $42 \%$ & $46 \%$ \\
\hline $28 \%$ & $45 \%$ & $78 \%$ & $0 \%$ & $100 \%$ \\
\hline $52 \%$ & $65 \%$ & $73 \%$ & $51 \%$ & $50 \%$ \\
\hline $44 \%$ & $62 \%$ & $78 \%$ & $50 \%$ & $52 \%$ \\
\hline $50 \%$ & $64 \%$ & $53 \%$ & $42 \%$ & $40 \%$ \\
\hline $49 \%$ & $66 \%$ & $37 \%$ & $58 \%$ & $54 \%$ \\
\hline $27 \%$ & $47 \%$ & $60 \%$ & $27 \%$ & $31 \%$ \\
\hline $46 \%$ & $64 \%$ & $60 \%$ & $42 \%$ & $44 \%$ \\
\hline $31 \%$ & $51 \%$ & $50 \%$ & $33 \%$ & $40 \%$ \\
\hline $23 \%$ & $40 \%$ & $59 \%$ & $31 \%$ & $49 \%$ \\
\hline $65 \%$ & $76 \%$ & $88 \%$ & $46 \%$ & $46 \%$ \\
\hline $55 \%$ & $68 \%$ & $87 \%$ & $37 \%$ & $60 \%$ \\
\hline $69 \%$ & $80 \%$ & $87 \%$ & $40 \%$ & $45 \%$ \\
\hline $31 \%$ & $49 \%$ & $77 \%$ & $46 \%$ & $29 \%$ \\
\hline $29 \%$ & $46 \%$ & $31 \%$ & $36 \%$ & $36 \%$ \\
\hline $39 \%$ & $55 \%$ & $81 \%$ & $39 \%$ & $37 \%$ \\
\hline $31 \%$ & $47 \%$ & $83 \%$ & $32 \%$ & $44 \%$ \\
\hline $59 \%$ & $73 \%$ & $74 \%$ & $46 \%$ & $57 \%$ \\
\hline $55 \%$ & $66 \%$ & $80 \%$ & $48 \%$ & $42 \%$ \\
\hline $49 \%$ & $62 \%$ & $65 \%$ & $31 \%$ & $32 \%$ \\
\hline $42 \%$ & $60 \%$ & $50 \%$ & $46 \%$ & $49 \%$ \\
\hline $58 \%$ & $67 \%$ & $80 \%$ & $50 \%$ & $47 \%$ \\
\hline $24 \%$ & $38 \%$ & $55 \%$ & $26 \%$ & $28 \%$ \\
\hline $59 \%$ & $71 \%$ & $63 \%$ & $38 \%$ & $34 \%$ \\
\hline $39 \%$ & $51 \%$ & $89 \%$ & $18 \%$ & $0 \%$ \\
\hline $53 \%$ & $74 \%$ & $51 \%$ & $23 \%$ & $45 \%$ \\
\hline $59 \%$ & $73 \%$ & $87 \%$ & $50 \%$ & $30 \%$ \\
\hline
\end{tabular}




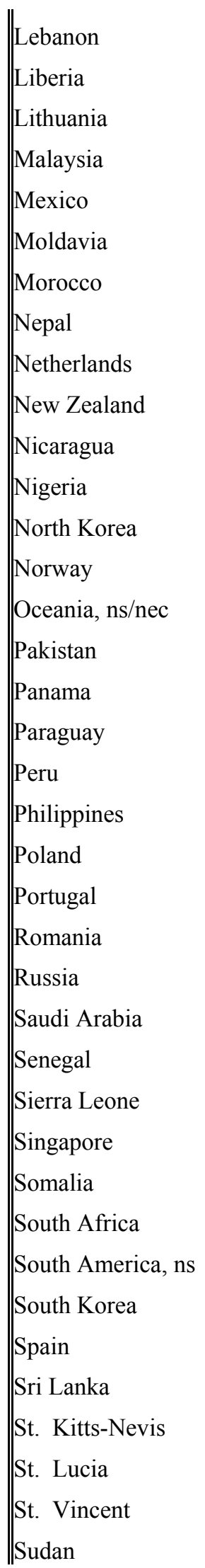

\begin{tabular}{|c|c|c|c|c|}
\hline $44 \%$ & $58 \%$ & $85 \%$ & $36 \%$ & $35 \%$ \\
\hline $41 \%$ & $61 \%$ & $52 \%$ & $41 \%$ & $36 \%$ \\
\hline $31 \%$ & $50 \%$ & $40 \%$ & $61 \%$ & $80 \%$ \\
\hline $67 \%$ & $81 \%$ & $85 \%$ & $50 \%$ & $57 \%$ \\
\hline $24 \%$ & $43 \%$ & $36 \%$ & $21 \%$ & $27 \%$ \\
\hline $49 \%$ & $65 \%$ & $56 \%$ & $0 \%$ & $17 \%$ \\
\hline $30 \%$ & $48 \%$ & $35 \%$ & $31 \%$ & $40 \%$ \\
\hline $31 \%$ & $41 \%$ & $94 \%$ & $27 \%$ & $35 \%$ \\
\hline $55 \%$ & $66 \%$ & $79 \%$ & $54 \%$ & $66 \%$ \\
\hline $56 \%$ & $65 \%$ & $89 \%$ & $62 \%$ & $56 \%$ \\
\hline $27 \%$ & $43 \%$ & $28 \%$ & $26 \%$ & $31 \%$ \\
\hline $42 \%$ & $59 \%$ & $72 \%$ & $50 \%$ & $36 \%$ \\
\hline $45 \%$ & $59 \%$ & $79 \%$ & $36 \%$ & $35 \%$ \\
\hline $50 \%$ & $61 \%$ & $75 \%$ & $59 \%$ & $18 \%$ \\
\hline $30 \%$ & $48 \%$ & $26 \%$ & $46 \%$ & $0 \%$ \\
\hline $38 \%$ & $55 \%$ & $80 \%$ & $33 \%$ & $41 \%$ \\
\hline $43 \%$ & $60 \%$ & $61 \%$ & $39 \%$ & $54 \%$ \\
\hline $9 \%$ & $18 \%$ & $10 \%$ & $0 \%$ & $64 \%$ \\
\hline $29 \%$ & $48 \%$ & $42 \%$ & $32 \%$ & $27 \%$ \\
\hline $39 \%$ & $57 \%$ & $62 \%$ & $32 \%$ & $42 \%$ \\
\hline $35 \%$ & $55 \%$ & $65 \%$ & $25 \%$ & $35 \%$ \\
\hline $51 \%$ & $64 \%$ & $63 \%$ & $36 \%$ & $32 \%$ \\
\hline $40 \%$ & $59 \%$ & $70 \%$ & $41 \%$ & $40 \%$ \\
\hline $45 \%$ & $63 \%$ & $61 \%$ & $41 \%$ & $49 \%$ \\
\hline $38 \%$ & $51 \%$ & $79 \%$ & $58 \%$ & $0 \%$ \\
\hline $24 \%$ & $39 \%$ & $28 \%$ & $34 \%$ & $0 \%$ \\
\hline $42 \%$ & $61 \%$ & $29 \%$ & $26 \%$ & $46 \%$ \\
\hline $68 \%$ & $79 \%$ & $81 \%$ & $74 \%$ & $58 \%$ \\
\hline $34 \%$ & $55 \%$ & $53 \%$ & $50 \%$ & $100 \%$ \\
\hline $69 \%$ & $78 \%$ & $88 \%$ & $56 \%$ & $39 \%$ \\
\hline $45 \%$ & $64 \%$ & $42 \%$ & $16 \%$ & $46 \%$ \\
\hline $38 \%$ & $53 \%$ & $78 \%$ & $27 \%$ & $31 \%$ \\
\hline $44 \%$ & $56 \%$ & $74 \%$ & $53 \%$ & $64 \%$ \\
\hline $57 \%$ & $70 \%$ & $89 \%$ & $47 \%$ & $55 \%$ \\
\hline $43 \%$ & $62 \%$ & $45 \%$ & $55 \%$ & $26 \%$ \\
\hline $46 \%$ & $64 \%$ & $48 \%$ & $63 \%$ & $65 \%$ \\
\hline $36 \%$ & $53 \%$ & $90 \%$ & $40 \%$ & $0 \%$ \\
\hline $34 \%$ & $54 \%$ & $68 \%$ & $4 \%$ & $0 \%$ \\
\hline
\end{tabular}




\begin{tabular}{||l|c|c|c||c|c||} 
Sweden & $57 \%$ & $69 \%$ & $74 \%$ & $44 \%$ & $40 \%$ \\
Switzerland & $56 \%$ & $67 \%$ & $71 \%$ & $69 \%$ & $58 \%$ \\
Syria & $20 \%$ & $30 \%$ & $74 \%$ & $31 \%$ & $43 \%$ \\
Taiwan & $55 \%$ & $67 \%$ & $79 \%$ & $45 \%$ & $54 \%$ \\
Tanzania & $37 \%$ & $52 \%$ & $37 \%$ & $41 \%$ & $53 \%$ \\
Thailand & $29 \%$ & $43 \%$ & $84 \%$ & $14 \%$ & $36 \%$ \\
Tonga & $14 \%$ & $23 \%$ & $99 \%$ & $5 \%$ & $0 \%$ \\
Trinidad \& Tobago & $51 \%$ & $67 \%$ & $81 \%$ & $40 \%$ & $52 \%$ \\
Turkey & $42 \%$ & $60 \%$ & $85 \%$ & $35 \%$ & $58 \%$ \\
Uganda & $51 \%$ & $66 \%$ & $85 \%$ & $47 \%$ & $50 \%$ \\
Ukraine & $39 \%$ & $58 \%$ & $62 \%$ & $46 \%$ & $29 \%$ \\
United Kingdom & $66 \%$ & $76 \%$ & $78 \%$ & $61 \%$ & $57 \%$ \\
Uruguay & $33 \%$ & $47 \%$ & $71 \%$ & $46 \%$ & $47 \%$ \\
Uzbekistan & $36 \%$ & $54 \%$ & $39 \%$ & $54 \%$ & $32 \%$ \\
Venezuela & $45 \%$ & $61 \%$ & $64 \%$ & $35 \%$ & $28 \%$ \\
Vietnam & $42 \%$ & $60 \%$ & $69 \%$ & $39 \%$ & $42 \%$ \\
West Indies, ns & $35 \%$ & $50 \%$ & $73 \%$ & $51 \%$ & $40 \%$ \\
Western Samoa & $36 \%$ & $57 \%$ & $37 \%$ & $29 \%$ & $27 \%$ \\
Yemen & $24 \%$ & $39 \%$ & $26 \%$ & $0 \%$ & $42 \%$ \\
Yugoslavia (former) & $29 \%$ & $49 \%$ & $59 \%$ & $21 \%$ & $31 \%$ \\
\hline
\end{tabular}


TABLE 3 - Probability of Obtaining Different Jobs for Professional Degree Holders, by cohort

\begin{tabular}{|c|c|c|c|c|c|c|}
\hline & Skilled & Science & Profession & $\begin{array}{c}\text { Professional } \\
\text { Support }\end{array}$ & Technical & $\overline{\text { Unskilled }}$ \\
\hline \multicolumn{7}{|l|}{$1990 \mathrm{~s}$} \\
\hline Brazil & $29 \%$ & $7 \%$ & $21 \%$ & $7 \%$ & $13 \%$ & $22 \%$ \\
\hline Canada & $23 \%$ & $4 \%$ & $62 \%$ & $2 \%$ & $7 \%$ & $2 \%$ \\
\hline China & $29 \%$ & $15 \%$ & $33 \%$ & $4 \%$ & $8 \%$ & $11 \%$ \\
\hline Egypt & $9 \%$ & $1 \%$ & $70 \%$ & $2 \%$ & $6 \%$ & $12 \%$ \\
\hline India & $27 \%$ & $3 \%$ & $58 \%$ & $3 \%$ & $5 \%$ & $5 \%$ \\
\hline Japan & $31 \%$ & $15 \%$ & $34 \%$ & $2 \%$ & $14 \%$ & $4 \%$ \\
\hline Mexico & $20 \%$ & $2 \%$ & $13 \%$ & $3 \%$ & $12 \%$ & $49 \%$ \\
\hline Nigeria & $16 \%$ & $4 \%$ & $52 \%$ & $11 \%$ & $6 \%$ & $11 \%$ \\
\hline Philippines & $18 \%$ & $5 \%$ & $39 \%$ & $16 \%$ & $6 \%$ & $16 \%$ \\
\hline Russia & $30 \%$ & $9 \%$ & $23 \%$ & $7 \%$ & $10 \%$ & $21 \%$ \\
\hline United Kingdom & $46 \%$ & $7 \%$ & $25 \%$ & $3 \%$ & $15 \%$ & $5 \%$ \\
\hline Vietnam & $22 \%$ & $8 \%$ & $39 \%$ & $4 \%$ & $7 \%$ & $20 \%$ \\
\hline \multicolumn{7}{|l|}{$1980 \mathrm{~s}$} \\
\hline Brazil & $25 \%$ & $14 \%$ & $30 \%$ & $5 \%$ & $14 \%$ & $13 \%$ \\
\hline Canada & $20 \%$ & $2 \%$ & $66 \%$ & $1 \%$ & $8 \%$ & $3 \%$ \\
\hline China & $33 \%$ & $10 \%$ & $27 \%$ & $3 \%$ & $15 \%$ & $13 \%$ \\
\hline Egypt & $19 \%$ & $3 \%$ & $54 \%$ & $2 \%$ & $13 \%$ & $10 \%$ \\
\hline India & $16 \%$ & $2 \%$ & $65 \%$ & $2 \%$ & $9 \%$ & $6 \%$ \\
\hline Japan & $26 \%$ & $2 \%$ & $55 \%$ & $1 \%$ & $11 \%$ & $5 \%$ \\
\hline Mexico & $20 \%$ & $4 \%$ & $24 \%$ & $3 \%$ & $14 \%$ & $35 \%$ \\
\hline Nigeria & $24 \%$ & $2 \%$ & $54 \%$ & $5 \%$ & $7 \%$ & $8 \%$ \\
\hline Philippines & $22 \%$ & $2 \%$ & $38 \%$ & $10 \%$ & $12 \%$ & $16 \%$ \\
\hline Russia & $15 \%$ & $2 \%$ & $68 \%$ & $2 \%$ & $7 \%$ & $7 \%$ \\
\hline United Kingdom & $38 \%$ & $3 \%$ & $41 \%$ & $2 \%$ & $11 \%$ & $5 \%$ \\
\hline Vietnam & $21 \%$ & $2 \%$ & $53 \%$ & $2 \%$ & $10 \%$ & $12 \%$ \\
\hline
\end{tabular}


TABLE 4 - Descriptive Statistics

\begin{tabular}{||l|c|c|c||}
\hline & $1990 \mathrm{~s}$ & $1980 \mathrm{~s}$ & $1970 \mathrm{~s}$ \\
\hline \hline Distance (miles) & 5,608 & 5,332 & 5159 \\
& {$[1,076-9,450]$} & {$[1,076-9,450]$} & {$[1,516-9,398]$} \\
\hline Military conflict & 0.333 & 0.265 & 0.269 \\
& {$[0-1]$} & {$[0-1]$} & {$[0-1]$} \\
\hline English & 0.411 & 0.515 & 0.577 \\
& {$[0-1]$} & {$[0-1]$} & {$[0-1]$} \\
\hline Tertiary education expenditure per & 4,039 & 4,625 & 5,625 \\
student (1995 const. \$ - PPP adjusted) & {$[298-29,856]$} & {$[160-20,041]$} & {$[295-21,673]$} \\
\hline Per capita GDP & 8,791 & 8,119 & 7,306 \\
(in 1995 const. \$ - PPP adjusted) & {$[556-27,781]$} & {$[617-23,893]$} & {$[589-21,523]$} \\
\hline Share of immigrants in origin country population & & & \\
& $5 \%$ & & - \\
(categories of immigrants: close family, & {$[0.02 \%-69 \%]$} & - & 52 \\
relatives, Diversity visa recipients, refugees) & & 68 & \\
\hline Number of observations & 90 & & \\
\hline
\end{tabular}

TABLE 5 - Country-level Determinants of Probability of Obtaining A Skilled Job - 1990s

\begin{tabular}{||l|c|c|c||}
\hline $\begin{array}{l}\text { Dependent variable: } \\
\text { Probability of entering a skilled profession }\end{array}$ & bachelor & masters & $\begin{array}{c}\text { professional } \\
\text { (skld, sci \& } \\
\text { prof) }\end{array}$ \\
\hline Log of distance to US & $0.057^{* *}$ & 0.033 & $0.110^{* *}$ \\
& $(2.32)$ & $(1.56)$ & $(2.70)$ \\
\hline Military conflict & $-0.143^{* * *}$ & $-0.127^{* * *}$ & $-0.095^{* * *}$ \\
& $(-3.47)$ & $(-4.10)$ & $(-3.29)$ \\
\hline English & $0.114^{* * *}$ & $0.079^{* *}$ & $0.120^{* * *}$ \\
& $(3.51)$ & $(2.87)$ & $(3.24)$ \\
\hline Log of tertiary education expenditure per student & $0.075^{* * *}$ & $0.069^{* * *}$ & $0.071^{* * *}$ \\
(PPP adjusted) & $(3.21)$ & $(3.14)$ & $(4.34)$ \\
\hline Log of per capita GDP & -0.016 & $-0.042^{* *}$ & -0.014 \\
(PPP adjusted) & $(-0.54)$ & $(-2.34)$ & $(-0.82)$ \\
\hline \hline Number of observations & 90 & 90 & 90 \\
F-statistic & $36.96^{* * *}$ & $17.87 * * *$ & $25.87 * * *$ \\
R-square & 0.656 & 0.557 & 0.726 \\
\hline
\end{tabular}

Notes: Weighted OLS regression with White robust standard errors. T-statistics in parentheses. *** denotes significance at the 1 percent level; ${ }^{* *}$ denotes significance at the 5 percent level; ${ }^{*}$ denotes significance at the 10 percent level. 
TABLE 6 - Country-level Determinants of Probability of Obtaining A Skilled Job - 1980s

\begin{tabular}{||l|c|c|c||}
\hline Dependent variable: & bachelor & masters & $\begin{array}{c}\text { professional } \\
\text { (skld, sci \& } \\
\text { prof) }\end{array}$ \\
\hline Probability of entering a skilled profession & & & \\
\hline Log of distance to US & $0.070^{* *}$ & 0.051 & $0.098^{* *}$ \\
& $(2.32)$ & $(1.45)$ & $(2.88)$ \\
\hline Military conflict & -0.039 & $-0.053^{* *}$ & -0.029 \\
& $(-1.20)$ & $(-2.17)$ & $(-0.75)$ \\
\hline English & 0.025 & 0.004 & $0.082^{* *}$ \\
& $(0.91)$ & $(0.15)$ & $(1.99)$ \\
\hline Log of tertiary education expenditure & $0.058^{* * *}$ & $0.043^{* *}$ & $0.059^{* *}$ \\
per student (PPP adjusted) & $(3.3)$ & $(2.12)$ & $(2.89)$ \\
\hline Log of per capita GDP & $0.031^{*}$ & 0.021 & 0.01 \\
(PPP adjusted) & $(1.76)$ & $(1.13)$ & $(0.47)$ \\
\hline Number of observations & 68 & 68 & 68 \\
F-statistic & $11.97^{* * *}$ & $5.70^{* * *}$ & $8.32^{* * *}$ \\
R-square & 0.581 & 0.416 & 0.536 \\
\hline \hline
\end{tabular}

Notes: Weighted OLS regression with White robust standard errors. T-statistics in parentheses. *** denotes significance at the 1 percent level; $* *$ denotes significance at the 5 percent level; $*$ denotes significance at the 10 percent level.

TABLE 7 - Country-level Determinants of Probability of Obtaining A Skilled Job - 1990s with immigration policy indicator included

\begin{tabular}{||l|c|c|c||}
\hline Dependent variable: & bachelor & masters & $\begin{array}{c}\text { professional } \\
\text { (skld, sci \& } \\
\text { prof) }\end{array}$ \\
\hline \hline Probability of entering a skilled profession & & & 0.072 \\
& & 0.019 & $(1.6)$ \\
\hline Military conflict & $(1.27)$ & $(0.85)$ & $-0.098^{* * *}$ \\
& $-0.141^{* * *}$ & $-0.124^{* * *}$ & $(-3.53)$ \\
\hline English & $(-3.52)$ & $(-4.08)$ & $0.123^{* * *}$ \\
& $0.117^{* * *}$ & $0.081^{* *}$ & $(3.83)$ \\
\hline Log of tertiary education expenditure & $(3.71)$ & $(2.94)$ & $0.055^{* * *}$ \\
per student (PPP adjusted) & $0.070^{* *}$ & $0.066^{* *}$ & $(3.22)$ \\
\hline Log of per capita GDP & $(2.85)$ & $(2.84)$ & -0.017 \\
(PPP adjusted) & -0.02 & $-0.043^{* *}$ & $(-1.05)$ \\
\hline Share of immigrants in origin country population & $(-0.66)$ & $(-2.39)$ & $-0.533^{* *}$ \\
(categories of immigrants: close family, relatives, & $-0.335^{* *}$ & $-0.245^{* *}$ & $(-2.22)$ \\
Diversity visa recipients, refugees) & $(-2.56)$ & $(-1.95)$ & \\
\hline \hline Number of observations & & & 90 \\
F-statistic & $36.77^{* * *}$ & $17.76^{* * *}$ & $20.39^{* * *}$ \\
R-square & 0.672 & 0.566 & 0.749 \\
\hline \hline
\end{tabular}

Notes: Weighted OLS regression with White robust standard errors. T-statistics in parentheses. *** denotes significance at the 1 percent level; ** denotes significance at the 5 percent level; * denotes significance at the 10 percent level 